\section{Hong Kong inquiry dispute}

SIR - We wish to comment on the letter from Mr John Griffiths on matters arising from our legal dispute with Dr T. H. Lam and the subsequent inquiry by the University of Hong Kong ${ }^{1}$. The Hong Kong University inquiry consisted of 14 closed meetings during 16 months. We were excluded from being a party. Griffiths, the barrister defending Lam, claims that new evidence was presented at the inquiry. We have not been allowed to see it.

Griffiths' comment that the university inquiry "received far more evidence than was called at the civil trial" is difficult to understand as the high court trial lasted at least three times longer and went over more than 20,000 pages of documents in open court. As stated in the judgement from the court of appeal ${ }^{2}$, "The trial lasted some 9 weeks and every conceivable point which could be raised was. . . . it is clear the Judge took the greatest care in analysing the evidence. . . I I am in no doubt that not only has derivation been proved, but also Dr Lam has copied a substantial part of Dr Koo's questionnaire. He has used someone else's skill and labour and unfairly produced it as though it was his own."

Griffiths cites the comments of 26 epidemiologists, but fails to point out that they received insufficient documents for analysis. There were 14 versions of our questionnaire and 4 of Lam's in dispute. A comparison of these documents with 8 other epidemiological questionnaires was made during the high court trial but not the university inquiry.

Griffiths is also inaccurate in saying that the sworn evidence of Koo at the high court trial was contradicted by the statements of two research assistants in the university inquiry. In the high court judgement ${ }^{3}$, it clearly states that "The 'used' Koo-Ho questionnaires are four in number. . . KH4a was used by Miss Carol Tong. . . KH4b was used by Miss Nancy Lee. . . KH3c is a translation into Chinese of $\mathrm{KH} 4 \mathrm{a}$. . . KH4d is the version kept by Dr Koo herself." Who possessed and used which version was not disputed by Griffiths in the court of appeal and Lee's testimony in the university inquiry did not contradict the high court judgement.

Griffiths' comment that our questionnaire was "inferior" is contrary to published assessments. From the 1986 US Surgeon General's report on The Health Consequences of Involuntary Smoking it is said: "The design of this study addressed the criticisms of other studies that an index of involuntary smoking exposures based only on spouses' smoking habits is inadequate, and broadened the exposure assessment to include all locations of tobacco smoke exposure." Others have said "I think we should encourage original research like that of Freedman 1983 on paper. .."5 surrogates for ETS and Koo's 1989

Griffiths and the university inquiry criticize the effects of the court judgements on the "free exchange of ideas" between scientists. Voluntary exchange of information between scientists is one thing, but when a colleague surreptitiously obtained 2 questionnaires that we laboured to produce, used it for his benefit and to our detriment, and without acknowledgement, then the issues at stake are morals and ethics.

J. H-C. Ho

Department of Radiation Oncology,

L. C. Koo

Department of Community Medicine,

University of Hong Kong, Hong Kong

\section{Griffiths. J. Nature 374, 301 (1995) \\ 2. Hong Kong Law Reports 1, 329-352 (1994) \\ 3. Intellectual Property Reports 23,607-640 (1993) \\ 4. US Surgeon Generat, The Health Consequences of Involuntary Smoking, 81 (US Dept of Health and Human Services, Washington, DC, 1986) \\ 5. Environmental Tobacco Smoke 127 (eds Ecobichon, D. ). \& Wu. J. M.) (Lexington Books, Lexington, Massachusetts).}

\section{Brazilian science}

SIR - I would like to comment on the report by your São Paolo correspondent on science in Brazil (Nature 373, 274; 1995) which contains some statements that are misleading and incorrect. First, it is obvious to Brazilian scientists that a measure of "reprieve from the hard times" they have faced came only after the fall of the government of Fernando Collor de Mello in 1992, and not since the beginning of the Collor administration, as your report states.

Second, the new president, Fernando Henrique Cardoso, is a well known social scientist who has since October 1992 been a minister first of foreign affairs, and subsequently of finance. He was therefore well aware of the importance of science and technology, and was an important participant in the reprieve of science and technology during Itamar Franco's administration.

The retention of the minister for science and technology might therefore be attributed to an appreciation of the minister's past performance both by the scientific community and by the new president, to whom he has been known for more than 40 years, rather than to a "low political significance" being attributed to the sector, as stated in your report.

Third, I have not made any claims, as your report suggests, to the rescue of the Programme of Support for Scientific and Technology Development (PADCT) or for obtaining funds for university-based research groups. Nevertheless, it remains true that there was an overall reduction of 50 per cent in the resources allocated to science and technology between the start of the Collor administration in 1990 and October 1992. Between then and 1994, we have not only returned to the pre-Collor level of spending, but have also obtained resources arising from privatization policies which have allowed for the reactivation, among other projects, of a certain number of university-based research groups.

\section{José Israel Vargas}

Ministerio de Ciencia e Tecnologia,

Esplanada dos Ministerios,

Bloco E, $4^{\circ}$ Andar,

70067-900 Brasilia,

Brasil

The apparent claim that Brazilian scientists have faced hard times since the fall of the Collor administration was a mistake introduced during editing. The other two issues raised by the minister are open to varying interpretations. Vargas's claim to have helped rescue the PADCT was made in an interview last year with the article's author.

\section{Future biodiversity}

SIR - Arguments for the ethical incentive to sustain biodiversity for future generations cannot be simply dismissed by analogy to "finite" abiotic resources such as water and air $^{1}$, or lead ${ }^{2}$. Elements are generally being moved around by humanity, not destroyed. Future generations could mine our wastegrounds for discarded 'non-renewable' resources, and if necessary use energy for restoration of molecules from component elements. Further, substitute energy sources can be anticipated (there is a lot of energy in the Solar System). In contrast, very few species could be re-created ${ }^{3}$ : you cannot re-create what you never knew, and our descendants will not even know how many species we extirpated ${ }^{4}$. Biodiversity is being irreversibly, consciously, and often unnecessarily destroyed; Beckerman's treatment of this central issue is superficial $^{1}$. Our failure to promote the survival of as many species (or rather their relatively immortal genes ${ }^{5}$ ) into the orbit of future generations is less ethical than theft.

\section{Cllve Hambler}

University of Oxford,

Department of Zoology,

South Parks Road,

Oxford OX1 3PS, UK

1. Beckerman, W. Small is Stupid (Duckworth, London, 1995)

2. Maddox, J. Nature 374, 305 (1995)

3. Hambler, C. Report on the Environmental Consequences of Uncontrolled Population Growth (Council of Europe. Strasbourg, 1994).

4. May, R. M. Science 241, 1441-1443 (1988)

4. May, R. M. Science 241, 1441-1443 (1988).
5. Dawkins, R. The Selfish Gene (Oxford Univ. Press, Oxford, 1976 